\title{
Polymorphisms of IGFI contribute to the development of ischemic stroke
}

\author{
HAK JAE KIM ${ }^{1 *}$, SU KANG KIM ${ }^{2 *}$, HAE JEONG PARK ${ }^{2}$, JOO-HO CHUNG ${ }^{2}$, \\ JINMAN CHUN ${ }^{3}$, DONG HWAN YUN ${ }^{3}$ and YOUNG OCK KIM ${ }^{4}$ \\ ${ }^{1}$ Soonchunhyang Medical Research Institute, College of Medicine, Soonchunhyang University, Chunan; \\ Departments of ${ }^{2}$ Pharmacology and Kohwang Medical Research Institute, and ${ }^{3}$ Physical Medicine \\ and Rehabilitation, School of Medicine, Kyung Hee University, Seoul; ${ }^{4}$ Development of Ginseng and \\ Medical Plants Research Institute, Rural Administration, Eumseong, Republic of Korea
}

Received August 1, 2011; Accepted September 1, 2011

DOI: $10.3892 /$ etm.2011.372

\begin{abstract}
Insulin-like growth factor 1 (IFG1) is neuroprotective in animal models of focal brain ischemia and correlates with ischemic stroke (IS) outcome in the elderly. In this study, we investigated whether single nucleotide polymorphisms (SNPs) of the IFG1 gene are associated with the development and clinical features of IS in a Korean population. A total of 119 patients with IS and 289 control subjects were recruited. Stroke patients were classified into subgroups according to the scores of the National Institutes of Health Stroke Survey (NIHSS; $<6$ and $\geq 6$ ) and the Modified Barthel Index (MBI; $<60$ and $\geq 60$ ). Among the SNPs of the IFG1 gene, five SNPs were selected and analyzed by direct sequencing: rs2162679 (intron), rs2195239 (intron), rs978458 (intron), rs1520220 (intron) and rs6214 (3' untranslated region; 3'UTR). Multiple logistic regression models were conducted to analyze genetic data. SNPStats, SNPAnalyzer Pro and Helixtree programs were used to calculate odds ratios (ORs), 95\% confidence intervals (CIs) and p-values. Two SNPs, rs2162679 and rs6214, were associated with the development of IS. After Bonferroni correction $\left(\mathrm{p}^{\mathrm{c}}\right)$, the $\mathrm{A}$ and $\mathrm{G}$ alleles of rs2162679 and rs6214 had significant differences between patients with IS and the controls [rs2162679, OR (95\% CI) $=1.64(1.17-2.31), \mathrm{p}=0.004, \mathrm{p}^{\mathrm{c}}=0.02$; rs6214, OR $\left.(95 \% \mathrm{CI})=1.52(1.12-2.07), \mathrm{p}=0.007, \mathrm{p}^{\mathrm{c}}=0.035\right]$, respectively. However, the five selected SNPs were not related to the NIHSS and MBI scores. These results suggest that IGFI may be associated with the development of IS.
\end{abstract}

Correspondence to: Dr Young-Ock Kim, Ginseng and Medical Plants Research Institute Rural Development Administration, Chunbuk 369-873, Republic of Korea

E-mail: kyo9128@korea.kr

*Contributed equally

Key words: insulin-like growth factor 1, ischemic stroke, Modified Barthel Index, National Institutes of Health Stroke Survey, single nucleotide polymorphism

\section{Introduction}

Stroke is a neurological disease which causes long-term disability and is the third leading cause of death in the United States. Ischemic stroke (IS) accounts for approximately $85 \%$ of all strokes. The other $9 \%$ are caused by intracerebral hemorrhage and $4-5 \%$ by subarachnoid hemorrhage $(1,2)$. Environmental and genetic factors are related to the pathogenesis of IS. Several lines of genetic studies have reported the relationship between IS and single nucleotide polymorphisms (SNPs) of candidate genes, such as the transforming growth factor $\beta 1$ (TGFB1), transforming growth factor $\beta$ receptor II (70/80 kDa) (TGFBR2) and tumor necrosis factor (TNF) (3-5).

Insulin-like growth factor 1 (somatomedin C) (IGF1) is similar to insulin in function and plays a crucial role in mammalian growth and development. The IGF1 level declines during the normal aging process, and a low IGF1 level correlates with decreased cognitive abilities (6). In vitro studies have shown that IGF1 reduces neuronal cell death in various injury insults $(7,8)$ and IGF1 has a protective effect in ischemic animal models $(9,10)$. Several reports have reviewed the roles of IGF1 in stroke severity and outcome $(11,12)$. They have suggested that IGF levels may be associated with neurological recovery and functional outcome, and have also proposed IGF1 as a predictor of stroke outcome.

In this study, we investigated the association between IGFI SNPs and IS in a Korean population. We also assessed the relationship between IGF1 SNPs and the clinical phenotypes according to the scores of National Institutes of Health Stroke Survey (NIHSS) and the Modified Barthel Index (MBI).

\section{Materials and methods}

Study population and clinical phenotypes. IS patients were enrolled among participants visiting the Departments of Neurosurgery and Physical Medicine and Rehabilitation, Kyung Hee Medical Center (Seoul, Republic of Korea). Patients with transient ischemic attack, cerebrovascular malformation, congenital brain disorders and accidental or iatrogenic stroke, were excluded. Stroke patients were diagnosed by computed tomography, magnetic resonance imaging, angiography and 


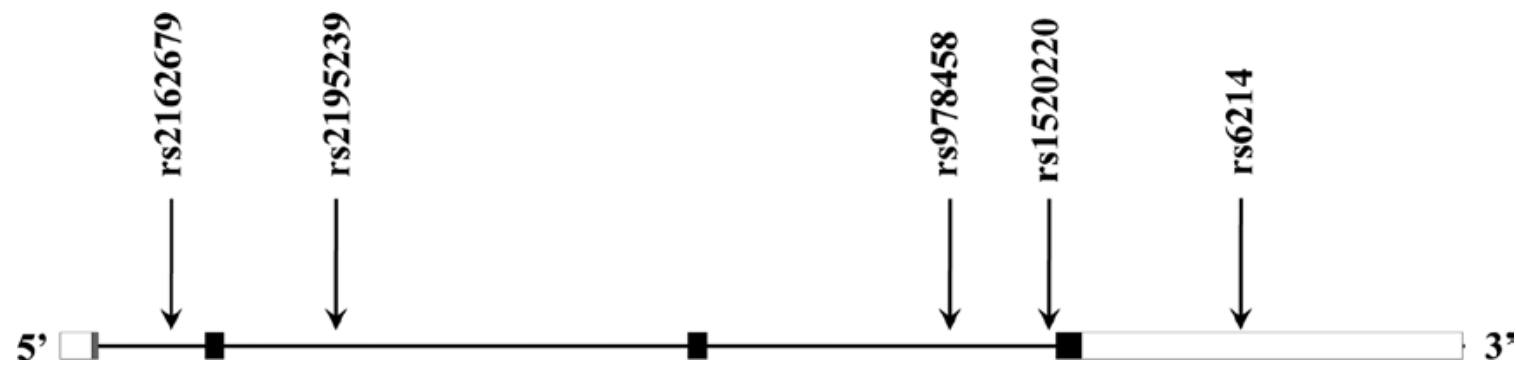

Figure 1. Gene map and single nucleotide polymorphisms in the $I G F$ gene on chromosome 12q23.2. Exons are marked with a box. The coding regions are represented by black boxes and untranslation regions by white boxes.

duplex sonography. The control subjects were recruited among healthy volunteers to examine the general health check-up program. Patients with neurological diseases, ischemic heart diseases and other severe diseases, were excluded. All stroke patients were classified into clinical phenotypes according to the NIHSS and MBI scores. For the neurological functional level of IS patient, the severity of 13 neurological symptoms was assessed by the NIHSS score. For the daily living activity of IS patients, the quality of 10 general life activities was evaluated by the MBI score. This study was approved by the Ethics Review Committee of the Medical Research Institute, School of Medicine, Kyung Hee University. Written informed consent was obtained from all patients. If patients were incommunicative, it was obtained from a guardian or close relatives.

SNP selection and genotyping. We searched the coding SNPs (cSNPs) of the IFG1 gene in the SNP database of the National Center for Biotechnology Information (http://www.ncbi.nlm. nih.gov/SNP, BUILD 132). The cSNPs with a heterozygosity of $<0.05$ and/or a minor allele frequency (MAF) of $<0.05$, were excluded. Out of five missense and two synonymous SNPs, there were no cSNPs with a heterozygosity of $>0.05$ or a MAF of $>0.05$. Therefore, we searched the untranslational and intron SNPs of the IGFI gene and previous studies (13-15). Finally, five SNPs [rs2162679 (intron), rs2195239 (intron), rs978458 (intron), rs1520220 (intron) and rs6214 (3' untranslated region; 3'UTR)] were selected (Fig. 1). Genotypes of the five selected SNPs were analyzed by direct sequencing (Macrogen, Seoul, Republic of Korea). Polymerase chain reactions (PCRs) were conducted using the forward and reverse primers of each SNP (Table II). PCRs were performed under the following conditions: 35 cycles at $95^{\circ} \mathrm{C}$ for $30 \mathrm{sec}, 58^{\circ} \mathrm{C}$ for $30 \mathrm{sec}, 72^{\circ} \mathrm{C}$ for $30 \mathrm{sec}$, and 1 cycle at $72^{\circ} \mathrm{C}$ for $5 \mathrm{~min}$ for the final reaction. The PCR products were sequenced by an ABI PRISM 3730XL analyzer (PE Applied Biosystems, Foster City, CA, USA) and genotypes of each SNP were analyzed by SeqManII software (DNASTAR, Madison, WI, USA).

Statistical analysis. SNPStats (http://bioinfo.iconcologia.net/ index.php?module=Snpstats), SNPAnalyzer Pro (ISTECH, Goyang, Republic of Korea), and Helixtree (Golden Helix, Bozeman, MT, USA) were used to obtain odds ratios (ORs), 95\% confidence intervals (CIs) and p-values. Hardy-Weinberg equilibrium (HWE) was calculated using the Chi-square test. Multiple logistic regression models were conducted using the following models: codominant1 (major allele homozygotes vs. heterozygotes), codominant2 (major allele homozygotes
Table I. Clinical characteristics in stroke patients and control subjects.

\begin{tabular}{lcc}
\hline & IS & Control \\
\hline Total no. & 119 & 289 \\
Male/female (n) & $66 / 53$ & $150 / 139$ \\
Age (mean \pm SD, years) & $65.8 \pm 12.1$ & $62.9 \pm 9.3$ \\
NIHSS (score) & & \\
$<6$ & 55 & \\
$\geq 6$ & 57 & \\
MBI (score) & & \\
$<60$ & 71 & \\
$\geq 60$ & 24 & \\
\hline
\end{tabular}

IS, ischemic stroke; SD, standard deviation; NIHSS, National Institutes of Health Stroke Survey; MBI, Modified Barthel Index. Stroke patients with inappropriate clinical data were excluded.

vs. minor allele homozygotes), dominant (major allele homozygotes vs. heterozygotes and minor allele homozygotes), recessive (major allele homozygotes and heterozygotes vs. minor allele homozygotes) and log-additive (major allele homozygotes vs. heterozygotes vs. minor allele homozygotes) $(16,17)$. Bonferroni correction was performed to obtain further statistical significance. Linkage disequilibrium (LD) blocks were estimated using Haploview version 4.2 (Daly Lab, Cambridge, MA, USA). The required case size in each SNP was estimated using the genetic power calculator (http://pngu.mgh.harvard.edu/ purcell/gpc/cc2.html) to obtain the statistical power. The statistical significant level was set at a value of $\mathrm{p}<0.05$.

\section{Results}

Demographic and clinical features of study subjects. Table I shows the demographic and clinical features of the IS patients and the control subjects. The age of the IS patients and control subjects was $65.8 \pm 12.1$ (mean $\pm \mathrm{SD}$ ) and $62.9 \pm 9.3$ years, respectively. The number of IS patients and control subjects was 119 (66 male/53 female) and 289 (150 male/139 female), respectively. All IS patients were divided into two clinical subgroups according to the NIHSS $(<6$ and $\geq 6)$ and MBI scores $(<60$ and $\geq 60$ ). The numbers of IS patients with a NIHSS score of $<6$ and $\geq 6$ were 55 (49.1\%) and 57 (50.9\%), respectively. The 
Table II. Primer sequences for each single nucleotide polymorphism (SNP).

\begin{tabular}{|c|c|c|c|}
\hline SNP & Forward $\left(5^{\prime}-3^{\prime}\right)$ & Reverse (5'-3') & Size (bp) \\
\hline rs2162679 & TCTGCAAGATCAATCACAGGTT & AAAAACCAAAACСССТGTCTCT & 386 \\
\hline rs2195239 & CAAATTTCAGCTGCGACTTTATC & GAGCCAAAACCATCTCTACACC & 306 \\
\hline rs978458 & TCCACTAGAGCCAAAGAAGAGC & GTGAAATGGTGGAGGATGATTT & 381 \\
\hline rs1520220 & AAAGGATCTAGAGGCCAGAAGG & AGTTCTTGTTTCCTGCACTCCC & 390 \\
\hline rs6214 & CCAGACATACAGGTTCTGTGGA & TTGGAGAGGATTATGTGTTGGA & 304 \\
\hline
\end{tabular}

Table III. Genotype and allele frequencies of $I G F$ singe nucleotide polymorphisms in controls and IS patients.

\begin{tabular}{|c|c|c|c|c|c|c|c|c|c|}
\hline \multirow[t]{2}{*}{ SNP } & \multirow[t]{2}{*}{ Type } & \multicolumn{2}{|c|}{ Control } & \multicolumn{2}{|c|}{ IS } & \multirow[t]{2}{*}{ Model } & \multirow[t]{2}{*}{ OR (95\% CI) } & \multirow[t]{2}{*}{ p-value } & \multirow[t]{2}{*}{$\mathrm{p}^{\mathrm{c}}$} \\
\hline & & $\mathrm{n}$ & $\%$ & $\mathrm{n}$ & $\%$ & & & & \\
\hline rs2162679 & $\mathrm{A} / \mathrm{A}$ & 120 & 41.5 & 63 & 53.9 & Codominant 1 & $0.68(0.43-1.07)$ & 0.0900 & 0.4500 \\
\hline \multirow[t]{6}{*}{ Intron } & $\mathrm{A} / \mathrm{G}$ & 129 & 44.6 & 48 & 41.0 & Codominant 2 & $0.27(0.11-0.67)$ & 0.0050 & 0.0250 \\
\hline & $\mathrm{G} / \mathrm{G}$ & 40 & 13.8 & 6 & 5.1 & Dominant & $0.58(0.37-0.90)$ & 0.0150 & 0.0800 \\
\hline & & & & & & Recessive & $0.32(0.13-0.79)$ & 0.0059 & 0.0295 \\
\hline & & & & & & Log-additive & $0.59(0.41-0.83)$ & 0.0020 & 0.0100 \\
\hline & $\mathrm{G}$ & 209 & 36.2 & 60 & 25.6 & & 1 & & \\
\hline & A & 369 & 63.8 & 174 & 74.4 & & $1.64(1.17-2.31)$ & 0.0040 & 0.0200 \\
\hline rs2195239 & $\mathrm{G} / \mathrm{G}$ & 93 & 32.2 & 43 & 36.1 & Codominant 1 & $0.84(0.53-1.36)$ & 0.4800 & 1.0000 \\
\hline \multirow[t]{6}{*}{ Intron } & $\mathrm{C} / \mathrm{G}$ & 152 & 52.6 & 60 & 50.4 & Codominant 2 & $0.78(0.39-1.54)$ & 0.4700 & 1.0000 \\
\hline & $\mathrm{C} / \mathrm{C}$ & 44 & 15.2 & 16 & 13.4 & Dominant & $0.83(0.53-1.30)$ & 0.4200 & 1.0000 \\
\hline & & & & & & Recessive & $0.86(0.46-1.61)$ & 0.6400 & 1.0000 \\
\hline & & & & & & Log-additive & $0.87(0.63-1.21)$ & 0.4100 & 1.0000 \\
\hline & $\mathrm{G}$ & 338 & 58.5 & 146 & 61.3 & & 1 & & \\
\hline & $\mathrm{C}$ & 240 & 41.5 & 92 & 38.7 & & $0.89(0.65-1.21)$ & 0.4500 & 1.0000 \\
\hline rs978458 & $\mathrm{G} / \mathrm{G}$ & 90 & 31.1 & 41 & 34.5 & Codominant 1 & $0.92(0.57-1.48)$ & 0.7200 & 1.0000 \\
\hline \multirow[t]{6}{*}{ Intron } & $\mathrm{A} / \mathrm{G}$ & 144 & 49.8 & 60 & 50.4 & Codominant 2 & $0.70(0.37-1.36)$ & 0.3000 & 1.0000 \\
\hline & $\mathrm{A} / \mathrm{A}$ & 55 & 19.0 & 18 & 15.1 & Dominant & $0.86(0.54-1.35)$ & 0.5100 & 1.0000 \\
\hline & & & & & & Recessive & $0.74(0.41-1.34)$ & 0.3200 & 1.0000 \\
\hline & & & & & & Log-additive & $0.85(0.62-1.17)$ & 0.3200 & 1.0000 \\
\hline & $\mathrm{G}$ & 324 & 56.1 & 142 & 59.7 & & 1 & & \\
\hline & A & 254 & 43.9 & 96 & 40.3 & & $0.86(0.64-1.17)$ & 0.3400 & 1.0000 \\
\hline rs 1520220 & $\mathrm{C} / \mathrm{C}$ & 90 & 31.1 & 41 & 34.8 & Codominant 1 & $0.93(0.57-1.50)$ & 0.7500 & 1.0000 \\
\hline \multirow[t]{6}{*}{ Intron } & $\mathrm{C} / \mathrm{G}$ & 143 & 49.5 & 60 & 50.9 & Codominant 2 & $0.64(0.33-1.25)$ & 0.2000 & 1.0000 \\
\hline & $\mathrm{G} / \mathrm{G}$ & 56 & 19.4 & 17 & 14.4 & Dominant & $0.85(0.53-1.34)$ & 0.4700 & 1.0000 \\
\hline & & & & & & Recessive & $0.68(0.37-1.23)$ & 0.1900 & 0.9500 \\
\hline & & & & & & Log-additive & $0.83(0.60-1.13)$ & 0.2300 & 1.0000 \\
\hline & $\mathrm{C}$ & 323 & 55.9 & 142 & 60.2 & & 1 & & \\
\hline & $\mathrm{G}$ & 255 & 44.1 & 94 & 39.8 & & $0.84(0.62-1.14)$ & 0.2600 & 1.0000 \\
\hline rs6214 & $\mathrm{G} / \mathrm{G}$ & 73 & 25.3 & 44 & 37.0 & Codominant 1 & $0.66(0.41-1.08)$ & 0.1000 & 0.5000 \\
\hline \multirow[t]{6}{*}{ 3'UTR } & $\mathrm{A} / \mathrm{G}$ & 144 & 49.8 & 56 & 47.1 & Codominant 2 & $0.44(0.23-0.83)$ & 0.0110 & 0.0600 \\
\hline & $\mathrm{A} / \mathrm{A}$ & 72 & 24.9 & 19 & 16.0 & Dominant & $0.59(0.37-0.93)$ & 0.0250 & 0.1300 \\
\hline & & & & & & Recessive & $0.57(0.32-1.00)$ & 0.0420 & 0.2100 \\
\hline & & & & & & Log-additive & $0.66(0.49-0.90)$ & 0.0088 & 0.0440 \\
\hline & A & 288 & 49.8 & 94 & 39.5 & & 1 & & \\
\hline & G & 290 & 50.2 & 144 & 60.5 & & $1.52(1.12-2.07)$ & 0.0070 & 0.0350 \\
\hline
\end{tabular}

The p-values were calculated from logistic regression analysis adjusting age and gender. Bold numbers indicate significant associations. IS, ischemic stroke; SNP, singe nucleotide polymorphism; OR, odds ratio; CI, confidence interval. 
Table IV. Genotype frequencies of $I G F$ singe nucleotide polymorphisms in stroke subgroups according to the NIHSS and MBI scores.

\begin{tabular}{|c|c|c|c|c|c|c|c|c|}
\hline \multirow[t]{2}{*}{ SNP } & \multirow[t]{2}{*}{ Type } & \multicolumn{4}{|c|}{ Subgroups } & \multirow[t]{2}{*}{ Model } & \multirow[t]{2}{*}{ OR $(95 \% \mathrm{CI})$} & \multirow[t]{2}{*}{$\mathrm{p}$-value } \\
\hline & & $\mathrm{n}$ & $\%$ & $\mathrm{n}$ & $\%$ & & & \\
\hline NHISS & & $(<6)$ & & $(\geq 6)$ & & & & \\
\hline rs2162679 & $\mathrm{A} / \mathrm{A}$ & 27 & 49.1 & 32 & 58.2 & Codominant 1 & $0.63(0.29-1.38)$ & 0.25 \\
\hline \multirow[t]{4}{*}{ Intron } & $\mathrm{A} / \mathrm{G}$ & 26 & 47.3 & 20 & 36.4 & Codominant 2 & $1.26(0.19-8.23)$ & 0.81 \\
\hline & $\mathrm{G} / \mathrm{G}$ & 2 & 3.6 & 3 & 5.5 & Dominant & $0.67(0.31-1.45)$ & 0.31 \\
\hline & & & & & & Recessive & $1.56(0.25-9.79)$ & 0.63 \\
\hline & & & & & & Log-additive & $0.79(0.41-1.53)$ & 0.49 \\
\hline rs2195239 & $\mathrm{G} / \mathrm{G}$ & 23 & 41.8 & 16 & 28.1 & Codominant 1 & $2.00(0.87-4.59)$ & 0.10 \\
\hline \multirow[t]{4}{*}{ Intron } & $\mathrm{C} / \mathrm{G}$ & 24 & 43.6 & 33 & 57.9 & Codominant 2 & $1.46(0.45-4.73)$ & 0.53 \\
\hline & $\mathrm{C} / \mathrm{C}$ & 8 & 14.6 & 8 & 14.0 & Dominant & $1.87(0.84-4.12)$ & 0.12 \\
\hline & & & & & & Recessive & $0.97(0.34-2.80)$ & 0.95 \\
\hline & & & & & & Log-additive & $1.36(0.77-2.38)$ & 0.28 \\
\hline rs978458 & $\mathrm{G} / \mathrm{G}$ & 22 & 40.0 & 15 & 26.3 & Codominant 1 & $1.89(0.82-4.39)$ & 0.14 \\
\hline \multirow[t]{4}{*}{ Intron } & $\mathrm{A} / \mathrm{G}$ & 25 & 45.5 & 32 & 56.1 & Codominant 2 & $1.87(0.60-5.87)$ & 0.28 \\
\hline & $\mathrm{A} / \mathrm{A}$ & 8 & 14.6 & 10 & 17.5 & Dominant & $1.89(0.85-4.21)$ & 0.12 \\
\hline & & & & & & Recessive & $1.27(0.46-3.51)$ & 0.65 \\
\hline & & & & & & Log-additive & $1.46(0.83-2.54)$ & 0.18 \\
\hline rs1520220 & $\mathrm{C} / \mathrm{C}$ & 22 & 40.0 & 15 & 26.8 & Codominant 1 & $1.77(0.76-4.10)$ & 0.18 \\
\hline \multirow[t]{4}{*}{ Intron } & $\mathrm{C} / \mathrm{G}$ & 26 & 47.3 & 31 & 55.4 & Codominant 2 & $2.12(0.66-6.86)$ & 0.21 \\
\hline & $\mathrm{G} / \mathrm{G}$ & 7 & 12.7 & 10 & 17.9 & Dominant & $1.84(0.83-4.12)$ & 0.13 \\
\hline & & & & & & Recessive & $1.50(0.52-4.28)$ & 0.45 \\
\hline & & & & & & Log-additive & $1.52(0.86-2.67)$ & 0.14 \\
\hline rs6214 & $\mathrm{G} / \mathrm{G}$ & 20 & 36.4 & 21 & 36.8 & Codominant 1 & $0.96(0.42-2.20)$ & 0.92 \\
\hline \multirow[t]{4}{*}{ 3'UTR } & $\mathrm{A} / \mathrm{G}$ & 27 & 49.1 & 26 & 45.6 & Codominant 2 & $1.22(0.40-3.73)$ & 0.73 \\
\hline & $\mathrm{A} / \mathrm{A}$ & 8 & 14.6 & 10 & 17.5 & Dominant & $1.02(0.47-2.23)$ & 0.96 \\
\hline & & & & & & Recessive & $1.25(0.45-3.45)$ & 0.67 \\
\hline & & & & & & Log-additive & $1.07(0.63-1.84)$ & 0.79 \\
\hline MBI & & $(<60)$ & & $(\geq 60)$ & & & & \\
\hline rs2162679 & $\mathrm{A} / \mathrm{A}$ & 37 & 53.6 & 15 & 62.5 & Codominant 1 & $0.96(0.35-2.65)$ & 0.94 \\
\hline \multirow[t]{4}{*}{ Intron } & $\mathrm{A} / \mathrm{G}$ & 29 & 42.0 & 9 & 37.5 & Codominant 2 & $0.00(0.00-\mathrm{NA})$ & \\
\hline & $\mathrm{G} / \mathrm{G}$ & 3 & 4.3 & 0 & 0.0 & Dominant & $0.91(0.33-2.50)$ & 0.85 \\
\hline & & & & & & Recessive & $0.00(0.00-\mathrm{NA})$ & 0.32 \\
\hline & & & & & & Log-additive & $0.83(0.32-2.15)$ & 0.70 \\
\hline rs2195239 & $\mathrm{G} / \mathrm{G}$ & 25 & 35.2 & 8 & 33.3 & Codominant 1 & $1.06(0.36-3.12)$ & 0.91 \\
\hline \multirow[t]{4}{*}{ Intron } & $\mathrm{C} / \mathrm{G}$ & 36 & 50.7 & 13 & 54.2 & Codominant 2 & $0.86(0.17-4.33)$ & 0.86 \\
\hline & $\mathrm{C} / \mathrm{C}$ & 10 & 14.1 & 3 & 12.5 & Dominant & $1.02(0.36-2.88)$ & 0.97 \\
\hline & & & & & & Recessive & $0.83(0.19-3.61)$ & 0.80 \\
\hline & & & & & & Log-additive & $0.96(0.46-2.03)$ & 0.92 \\
\hline rs978458 & $\mathrm{G} / \mathrm{G}$ & 24 & 33.8 & 7 & 29.2 & Codominant 1 & $1.40(0.46-4.25)$ & 0.55 \\
\hline \multirow[t]{4}{*}{ Intron } & $\mathrm{A} / \mathrm{G}$ & 35 & 49.3 & 14 & 58.3 & Codominant 2 & $0.83(0.17-4.15)$ & 0.82 \\
\hline & $\mathrm{A} / \mathrm{A}$ & 12 & 16.9 & 3 & 12.5 & Dominant & $1.26(0.43-3.66)$ & 0.67 \\
\hline & & & & & & Recessive & $0.67(0.16-2.82)$ & 0.58 \\
\hline & & & & & & Log-additive & $1.00(0.48-2.07)$ & 1.00 \\
\hline rs1520220 & $\mathrm{C} / \mathrm{C}$ & 24 & 34.3 & 7 & 29.2 & Codominant 1 & $1.44(0.47-4.36)$ & 0.52 \\
\hline \multirow[t]{4}{*}{ Intron } & $\mathrm{C} / \mathrm{G}$ & 35 & 50.0 & 14 & 58.3 & Codominant 2 & $0.90(0.18-4.57)$ & 0.90 \\
\hline & $\mathrm{G} / \mathrm{G}$ & 11 & 15.7 & 3 & 12.5 & Dominant & $1.31(0.45-3.81)$ & 0.62 \\
\hline & & & & & & Recessive & $0.72(0.17-3.06)$ & 0.65 \\
\hline & & & & & & Log-additive & $1.04(0.50-2.17)$ & 0.92 \\
\hline
\end{tabular}


Table IV. Continued.

\begin{tabular}{|c|c|c|c|c|c|c|c|c|}
\hline \multirow[t]{2}{*}{ SNP } & \multirow[t]{2}{*}{ Type } & \multicolumn{4}{|c|}{ Subgroups } & \multirow[t]{2}{*}{ Model } & \multirow[t]{2}{*}{ OR $(95 \% \mathrm{CI})$} & \multirow[t]{2}{*}{$\mathrm{p}$-value } \\
\hline & & $\mathrm{n}$ & $\%$ & $\mathrm{n}$ & $\%$ & & & \\
\hline rs6214 & $\mathrm{G} / \mathrm{G}$ & 26 & 36.6 & 10 & 41.7 & Codominant1 & $0.41(0.13-1.32)$ & 0.14 \\
\hline \multirow[t]{4}{*}{ 3'UTR } & $\mathrm{A} / \mathrm{G}$ & 37 & 52.1 & 8 & 33.3 & Codominant2 & $1.56(0.40-6.13)$ & 0.53 \\
\hline & $\mathrm{A} / \mathrm{A}$ & 8 & 11.3 & 6 & 25.0 & Dominant & $0.62(0.22-1.75)$ & 0.37 \\
\hline & & & & & & Recessive & $2.50(0.73-8.61)$ & 0.15 \\
\hline & & & & & & Log-additive & $1.06(0.52-2.17)$ & 0.86 \\
\hline
\end{tabular}

The p-values were evaluated from logistic regression analysis adjusting age and gender. Subjects with an undetected genotype were excluded. SNP, singe nucleotide polymorphism; NIHSS, National Institutes of Health Stroke Survey; MBI, Modified Barthel Index; OR, odds ratio; CI, confidence interval.

numbers of IS patients with a MBI score of $<60$ and $\geq 60$ were 71 (74.7\%) and 24 (25.3\%), respectively. In two clinical subgroups, patients with inappropriate or insufficient clinical data, were excluded (Table I).

Genetic analysis of IGF1 SNPs. Table III represents the genotype and allele frequencies of the five examined SNPs (rs2162679, rs2195239, rs978458, rs1520220 and rs6214) in the IS patients and the control subjects. The HWE of the five SNPs showed no difference in the control group ( $r 2162679, \mathrm{p}=0.61$; rs2195239, $\mathrm{p}=0.18$; rs978458, $\mathrm{p}=0.91 ; \mathrm{rs} 1520220, \mathrm{p}=1.00$; rs6214, $\mathrm{p}=1.00$ ). Multiple logistic regression analysis adjusting for age and gender was performed. An intron SNP (rs2162679) was associated with the development of IS $[\mathrm{p}=0.0050$, $\mathrm{OR}=0.27,95 \% \mathrm{CI}=0.11-0.67$ in the codominant 2 model (A/A vs. $\mathrm{G} / \mathrm{G}) ; \mathrm{p}=0.0150, \mathrm{OR}=0.58,95 \% \mathrm{CI}=0.37-0.90$ in the dominant model (A/A vs. $A / G$ and $G / G) ; p=0.0059$, $\mathrm{OR}=0.32,95 \% \mathrm{CI}=0.13-0.79$ in the recessive model $(\mathrm{A} / \mathrm{A}$ and $\mathrm{A} / \mathrm{G}$ vs. $\mathrm{G} / \mathrm{G})$; and $\mathrm{p}=0.0020, \mathrm{OR}=0.59,95 \% \mathrm{CI}=0.41-$ 0.83 in the log-additive model (A/A vs. A/G vs. G/G)]. A 3'UTR SNP (rs6214) was also associated with the development of IS $[\mathrm{p}=0.0110, \mathrm{OR}=0.44,95 \% \mathrm{CI}=0.23-0.83$ in the codominant 2 model (G/G vs. A/A); $\mathrm{p}=0.0250$, OR $=0.59$, $95 \% \mathrm{CI}=0.37-0.93$ in the dominant model $(\mathrm{G} / \mathrm{G}$ vs. $\mathrm{A} / \mathrm{G}$ and $\mathrm{A} / \mathrm{A}) ; \mathrm{p}=0.0420, \mathrm{OR}=0.57,95 \% \mathrm{CI}=0.32-1.00$ in the recessive model $(\mathrm{G} / \mathrm{G}$ and $\mathrm{A} / \mathrm{G}$ vs. $\mathrm{A} / \mathrm{A})$; and $\mathrm{p}=0.0088, \mathrm{OR}=0.66$, $95 \% \mathrm{CI}=0.49-0.90$ in the log-additive model (G/G vs. A/G vs. $\mathrm{A} / \mathrm{A})]$. The A allele frequency of rs2162679 was higher in the IS group $(74.4 \%)$ than in the control group $(63.8 \%)(p=0.004$, $\mathrm{OR}=1.64,95 \% \mathrm{CI}=1.17-2.31)$. The $\mathrm{G}$ allele frequency of rs6214 was higher in the IS group $(60.5 \%)$ than in the control group $(50.2 \%)(\mathrm{p}=0.007, \mathrm{OR}=1.52,95 \% \mathrm{CI}=1.12-2.07)$. After Bonferroni correction $\left(\mathrm{p}^{\mathrm{c}}\right)$, the allele frequencies of rs2162679 and rs6214 showed significant differences between IS and the controls (rs2162679, $\left.\mathrm{p}^{\mathrm{c}}=0.004 ; \mathrm{rs} 6214, \mathrm{p}^{\mathrm{c}}=0.007\right)$. The other SNPs (rs2195239, rs978458 and rs1520220) had no differences between IS and the controls (Table III). The LD block was estimated using Haploview version 4.2. One LD block was strongly made between rs1520220 and rs978458 $\left(\mathrm{D}^{\prime}=1.0\right.$ and $\mathrm{r}^{2}=0.993$ in the control group). However, the haplotypes of these two SNPs were not associated with the development of IS (data not shown). IS patients were classified into two clinical subgroups according to the NIHSS $(<6$ and $\geq 6)$ and
MBI ( $<60$ and $\geq 60)$ scores. As shown in Table IV, the five tested SNPs were not associated with the NIHSS and MBI scores.

Sample power. We estimated the sample power using a genetic power calculator to obtain the required sample size. The sample powers $(\alpha=0.05$, genotype relative risk 2 -fold, number of case for $70 \%$ power) of each SNP in the IS group were 0.757 for rs2162679 $(n=104), 0.800$ for rs2195239 $(n=93), 0.801$ for rs978458 $(n=93), 0.801$ for $r s 1520220(n=93)$ and 0.801 for rs6214 ( $n=93)$. Therefore, the results of the five examined SNPs in the IGF1 gene had statistical confidence.

\section{Discussion}

IGF1 is an endogenous survival factor for neurons, glial cells and endothelial cells. IGF1 plays an important role in tissue repair and cell proliferation. IGF1 induces the synthesis of elastin and prevents apoptosis of vascular smooth muscle cells. Therefore, low levels of IGF1 may be a risk factor of stroke. As shown in previous studies, the expression of IGF1 increased after hypoxic injury in regions with neuronal loss (18) and IGF1 reduced infarct volume and improved neurological function after ischemia in an animal study (19).

There are several reports that $I G F 1$ polymorphisms are associated with certain diseases, such as adenocarcinoma (EAC) and colorectal cancer $(15,20)$. McElholm et al observed that IGF1 SNP rs6214 was associated with Barrett's esophagus (BE) in EAC (15). Using GG genotype as reference, OR for BE in AA (wild-type) was 0.43 (95\% CI 0.24-0.75). Feik et al also suggested that rs6214 could have an impact on developing colorectal cancer and colorectal polyps with villous elements (20). Based on previous studies, we believed that the SNPs of IGF1 were associated with the development of IS and clinical features according to the NIHSS and MBI scores in Korean stroke patients. In the present study, we found a significant association between IGF1 SNPs and IS. The G allele frequency of rs6214 in the IGF1 gene was higher in the IS group (60.5\%) than in the control group (50.2\%). The A allele of rs2162679 was also higher in the IS group (74.4\%) than in the control group (74.4\%). Thus, our results suggest that IGF1 may be a risk factor of IS development. However, all five SNPs (rs2162679, rs2195239, rs978458, rs1520220 and rs6214) of IGF1 did not contribute to the NIHSS and MBI scores of 
IS. To our knowledge, this is the first study on whether IGFI SNPs are associated with the development of IS in a Korean population. Additional studies with a larger number of cases or different populations are required in order to confirm our results.

In conclusion, we suggest that an intron SNP (rs2162679) and 3'UTR SNP (rs6214) of the IGF1 gene may be associated with the development of IS.

\section{Acknowledgments}

This work was supported by the Biogreen 21 Program (Code PJ007187), Rural Development Administration

\section{References}

1. Grysiewicz RA, Thomas K and Pandey DK: Epidemiology of ischemic and hemorrhagic stroke: incidence, prevalence, mortality, and risk factors. Neurol Clin 26: 871-895, 2008.

2. Van Asch CJ, Luitse MJ, Rinkel GJ, et al: Incidence, case fatality, and functional outcome of intracerebral haemorrhage over time, according to age, sex, and ethnic origin: a systematic review and meta-analysis. Lancet Neurol 9: 167-176, 2010.

3. Tao HM, Chen GZ, Lu XD, Chen GP and Shao B: TGF-beta1 869T/C polymorphism and ischemic stroke: sex difference in Chinese. Can J Neurol Sci 37: 803-807, 2010.

4. Tong Y, Geng Y, Xu J, et al: The role of functional polymorphisms of the TNF-alpha gene promoter in the risk of ischemic stroke in Chinese Han and Uyghur populations: two case-control studies. Clin Chim Acta 411: 1291-1295, 2010.

5. Lim YH, Jeong YS, Kim SK, et al: Association between TGFBR2 gene polymorphism (rs2228048, Asn389Asn) and intracerebral hemorrhage in Korean Population. Immunol Invest 40: 569-580, 2011.

6. Kalmijn S, Janssen JA, Pols HA, Lamberts SW and Breteler MM: A prospective study on circulating insulin-like growth factor (IGF-I), IGF-binding proteins, and cognitive function in the elderly. J Clin Endocrinol Metab 85: 4551-4555, 2000.

7. Tagami M, Yamagata K, Nara Y, et al: Insulin-like growth factors prevent apoptosis in cortical neurons isolated from stroke-prone spontaneously hypertensive rats. Lab Invest 76: 603-612, 1997.
8. Galli C, Meucci O, Scorziello A, et al: Apoptosis in cerebellar granule cells is blocked by high $\mathrm{KCl}$, forskolin, and IGF-1 through distinct mechanisms of action: the involvement of intracellular calcium and RNA synthesis. J Neurosci 15: 1172-1179, 1995.

9. Kooijman R, Sarre S, Michotte Y and De Keyser J: Insulin-like growth factor I: a potential neuroprotective compound for the treatment of acute ischemic stroke? Stroke 40: e83-e88, 2009.

10. Guan J, Gunn AJ, Sirimanne ES, et al: The window of opportunity for neuronal rescue with insulin-like growth factor-1 after hypoxia-ischemia in rats is critically modulated by cerebral temperature during recovery. J Cereb Blood Flow Metab 20: 513-519, 2000.

11. De Smedt A, Brouns R, Uyttenboogaart M, et al: Insulin-like growth factor I serum levels influence ischemic stroke outcome. Stroke 42: 2180-2185, 2011

12. Bondanelli M, Ambrosio MR, Onofri A, et al: Predictive value of circulating insulin-like growth factor I levels in ischemic stroke outcome. J Clin Endocrinol Metab 91: 3928-3934, 2006.

13. Henningson $M$, Hietala $M$, Torngren $T$, Olsson $H$ and Jernstrom H: IGF1 htSNPs in relation to IGF-1 levels in young women from high-risk breast cancer families: implications for early-onset breast cancer. Fam Cancer 10: 173-185, 2010.

14. Hahn WH, Suh JS and Cho BS: Polymorphisms of insulin-like growth factor-1 (IGF-1) and IGF-1 receptor (IGF-1R) contribute to pathologic progression in childhood IgA nephropathy. Growth Factors 29: 8-13, 2010.

15. McElholm AR, McKnight AJ, Patterson CC, et al: A population-based study of IGF axis polymorphisms and the esophageal inflammation, metaplasia, adenocarcinoma sequence. Gastroenterology 139: 204-212, 2010.

16. Kim SK, Park HJ, Lee JS, et al: Association of niemann-pick disease, type c2 (NPC2) polymorphisms with obesity in Korean population. Mol Cell Toxicol 6: 395-400, 2010.

17. Lim TW, Kim SK, Ban JY, et al: Polymorphisms of transmembrane channel-like 1 gene are associated with Kawasaki disease in Korean population. Mol Cell Toxicol 5: 291-297, 2009.

18. Gluckman P, Klempt N, Guan J, et al: A role for IGF-1 in the rescue of CNS neurons following hypoxic-ischemic injury. Biochem Biophys Res Commun 182: 593-599, 1992.

19. Liu XF, Fawcett JR, Thorne RG and Frey WH II: Non-invasive intranasal insulin-like growth factor-I reduces infarct volume and improves neurologic function in rats following middle cerebral artery occlusion. Neurosci Lett 308: 91-94, 2001.

20. Feik E, Baierl A, Hieger B, et al: Association of IGF1 and IGFBP3 polymorphisms with colorectal polyps and colorectal cancer risk. Cancer Causes Control 21: 91-97, 2010. 